\title{
Sediment Studies at Bikini Atoll Part 1. Distribution of Fine and Coarse Components in Surface Sediments
}

Victor E. Noshkin

Rodney J. Eagle

William L. Robison 


\section{DISCLAIMER}

This document was prepared as an account of work sponsored by an agency of the United States Government. Neither the United States Government nor the University of California nor any of their employees, makes any warranty, express or implied, or assumes any legal liability or responsibility for the accuracy, completeness, or usefulness of any information, apparatus, product, or process disclosed, or represents that its use would not infringe privately owned rights. Reference herein to any specific commercial product, process, or service by trade name, trademark, manufacturer, or otherwise, does not necessarily constitute or imply its endorsement, recommendation, or favoring by the United States Government or the University of California. The views and opinions of authors expressed herein do not necessarily state or reflect those of the United States Government or the University of California, and shall not be used for advertising or product endorsement purposes.

This report has been reproduced directly from the best available copy.

Available to DOE and DOE contractors from the Office of Scientific and Technical Information P.O. Box 62, Oak Ridge, TN 37831

Prices available from (615) 576-8401, FTS 626-8401

Available to the public from the National Technical Information Service

U.S. Department of Commerce 5285 Port Royal Rd., Springfield, VA 22161

Work performed under the auspices of the U.S. Department of Energy by Lawrence Livermore National Laboratory under Contract W-7405-ENG-48. 
Sediment Studies at Bikini Atoll

Part 1. Distribution of Fine and Coarse Components in Surface Sediments

\author{
Victor E. Noshkin \\ Rodney J. Eagle \\ William L. Robison
}

Manuscript date: January 1997

Lawrence Livermore National Laboratory

University of California • Livermore, California • 94551 


\section{Table of Contents}

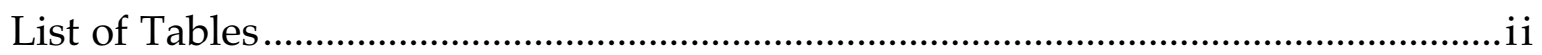

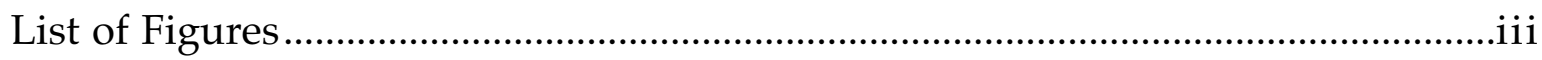

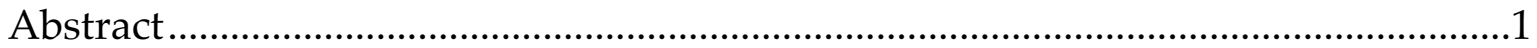

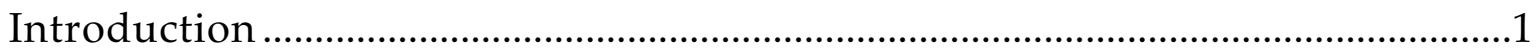

Materials and Methods ................................................................................

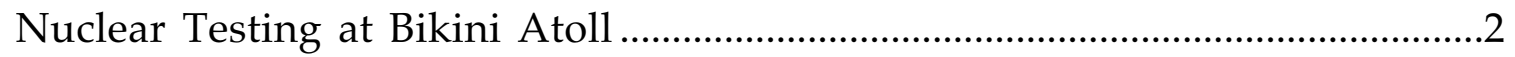

Collection and Processing Methods ...................................................................2

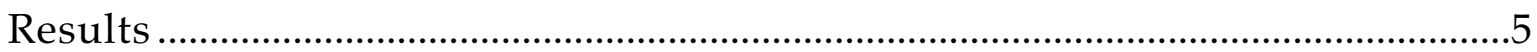

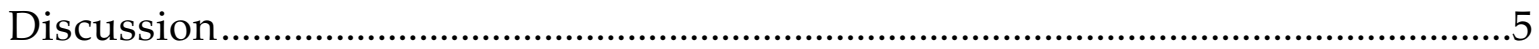

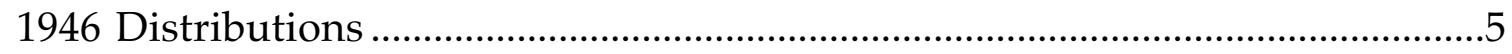

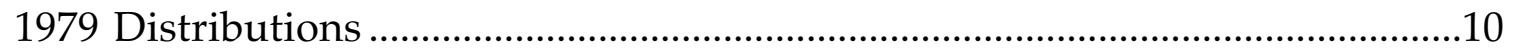

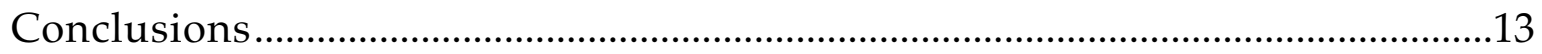

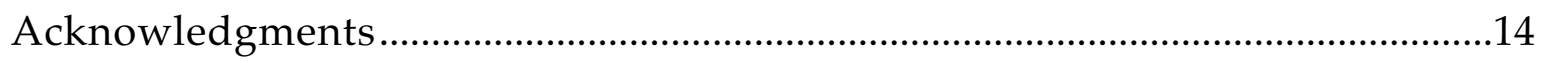

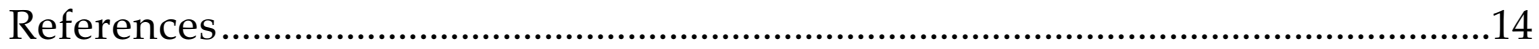

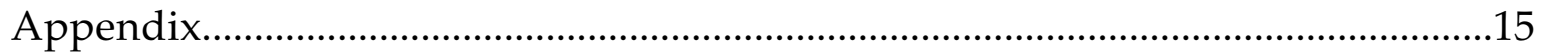




\section{List of Tables}

Table 1. Test Site Data and Crater Dimensions....................................................................

Table 2. Description of Major Materials in Bikini Lagoon Surface Sediment Collected

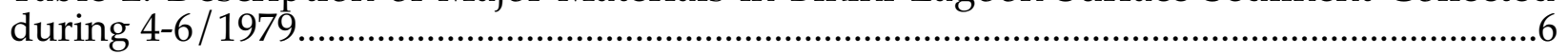

Table 3. Percentage of Fine Material in Surface $2 \mathrm{~cm}$ Layer of 1979 Bikini Lagoon

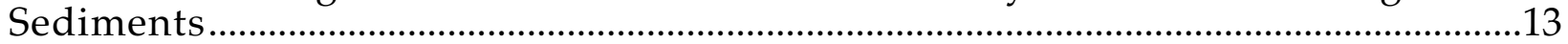




\section{List of Figures}

Figure 1. Names and Locations of Nuclear Tests at Bikini Atoll......................................

Figure 2. Distribution and $\%$ abundance lines of fine material $(<0.5 \mathrm{~mm})$ in the surface of Bikini lagoon sediment sampled in 1946..........................................................

Figure 3. Distribution and \% abundance lines of the remains of Halimeda algae in the surface of Bikini lagoon sediment sampled in 1946

Figure 4. Station locations defined in Table 2 and $\%$ abundance lines of fine material $(<0.5 \mathrm{~mm})$ in the surface of Bikini lagoon sediment sampled in 1979.........................11

Figure 5. Station locations defined in Table 2 and \% abundance lines of the remains of Halimeda algae in the surface of Bikini lagoon sediment sampled in 1979. 


\begin{abstract}
In 1979, 21 years after the moratorium on nuclear testing in the Marshall Islands, surface sediment samples (to depths of 2 and $4 \mathrm{~cm}$ ) were collected from 87 locations over the floor of Bikini lagoon. The main purpose for the collections was to map the distribution of long-lived man-made radionuclides associated with the bottom material. In addition the samples were processed to estimate the fraction of fine and coarse components to show what modifications occurred since the sediment composition was first described in samples collected before testing in 1946. In this report a comparison is made of the amount and distribution of fine material associated with the lagoon surface sediment before and after the testing of nuclear devices. Nuclear testing produced more finely divided material in the surface sediment layer over large areas of the lagoon and especially in regions of the lagoon and reef adjacent to test sites. Five cratering events at Bikini Atoll generated sufficient material to account for the inventory of new fine material found over the bottom surface of the lagoon. Although the fraction of fine material in the bottom sediments was altered by the nuclear events, the combined processes of formation, transport and deposition were not sufficiently dynamic to alter the geographical features of the major sedimentary components over most of the lagoon floor.
\end{abstract}

\title{
Introduction
}

A large scientific investigation of the natural environment of Bikini Atoll, located in the northern Marshall Islands at about $11^{\circ} 36^{\prime} \mathrm{N}, 165^{\circ} 22^{\prime} \mathrm{E}$, was undertaken in the spring of 1946 (Emery et al., 1954) prior to testing the first United States nuclear device at the Pacific Proving Grounds. One study described the distribution of the different components that made up the lagoon sediment. This was accomplished by collecting numerous bottom surface sediment samples from the lagoon. In the laboratory the percentage of the various components was estimated in about 900 samples. The chief components included Foraminifera, coral, skeletal remains of Halimeda algae, and shells of mollusks. Materials finer than about one-half a millimeter was not identified and grouped as fine debris. Other minor components, too rare to justify percentage estimates, included Lithothamnion and other coralline algae, echinoid spines, sponge spicules, and bryozoans. Maps showing the percentage of Foraminifera, Halimeda debris, fine debris and shells in the surface sediments were constructed (Emery et al., 1954) to describe the distribution of major components in the pre-test natural sedimentary environment.

Subsequently, 23 nuclear tests were detonated between 1946 and 1958 at Bikini Atoll. Each nuclear event contributed different quantities of radioactive fission products, some particle induced radionuclides and unspent nuclear fuel to the environment. These radionuclides became associated with the solid material incorporated into the fireball of the explosions and, depending on environmental and blast conditions, were transported to the troposphere and stratosphere and subsequently deposited as local, intermediate range and global fallout. Some local fallout was deposited on islands of Bikini and to the surface of the lagoon. Much of the fine pulverized material eventually settled to the surface of the bottom sediments. Internal waves, generated by surface explosions over water, moved sedimentary material previously deposited near test sites to different regions of the Atoll. These man-made and some natural processes, such as normal circulation, erosion, tropical storms and typhoons, probably altered the natural distribution and relative abundance of the fine material and other sedimentary components in the surface of the lagoon sediment.

In 1979, 21 years after the moratorium on testing in the Marshall Islands, surface sediment samples (to depths of 2 and $4 \mathrm{~cm}$ ) were collected from 87 locations over the floor of the lagoon. The main purpose for the collections was to map the distribution of long-lived manmade radionuclides associated with the bottom material. In addition the samples were 
processed to estimate the fraction of fine and coarse components to show what modifications occurred since Emery et al. (1954) first described these materials in the surface sediments. In this report a comparison is made of the amount and distribution of fine material associated with the lagoon surface sediment before and after the testing of nuclear devices. Other report in this series (Noshkin et al., 1997a; Noshkin et al., 1997b) will discuss the changes in inventories of some long-lived radionuclides associated with the bottom sediments from the lagoon.

\section{Materials and Methods}

\section{Nuclear Testing at Bikini Atoll}

The names of the tests and the regions where the tests were exploded are shown in Figure 1. Seventeen devices were exploded from barges anchored in the lagoon or on the reef, two were airburst detonations; one explosion was under water; and three were surface explosions on coral soil or the reef. The 23 tests were exploded at essentially 7 sites within the Atoll. Table 1 provides some information extracted from Cieceo and Nordyke (1964), Hawthorne (1979) and Lawson(1996) on each test exploded at the 7 regions. It is seen that many explosions occurred over ground zero locations of previous tests. In the region of the Bravo crater, for example, all five subsequent tests in the area (see Table 1) were conducted from barges anchored within a radius of $65 \mathrm{~m}$ from Bravo ground zero. The radius of the Bravo crater is $912 \mathrm{~m}$. Therefore even the Poplar event, the last test in this region, (see Table 1) was detonated approximately $80 \mathrm{~m}$ from the outer rim of Bravo crater. Approximately half of the total effective energy generated at Bikini over the entire nuclear testing program occurred in the region of Bravo crater. The cratering events (see Table 1) vaporized and resuspended considerable material to the atmosphere that eventually fell to earth including the local environment.

\section{Collection and Processing Methods}

During the late 1970's and early 1980's, the sediment studies were assigned a low priority compared to programs that complemented clean-up at Enewetak Atoll ; a large radiological survey of several other Northern Marshall Island Atolls ; and resettlement considerations for Bikini Atoll. As a result the sediment data were set aside to assess later. In 1984 the support for the marine studies in the Marshall Islands was terminated. Consequently, the sediment data from the 1979 program was again assigned a low priority and remained unpublished. Now there appears to be a requirement for sediment information since plans for the resettlement at Bikini Atoll call for dredging lagoon sediments as material for causeways and to replace contaminated soils on specific islands. Present support and facilities at the Atoll are not adequate to resample the entire lagoon bottom for new surface sediment samples. Information on radionuclide activity levels in, and the composition of, the sedimentary material will assist in assessing the better locations to dredge in the lagoon. Therefore data is presented and figures are constructed from the 1979 results to show the amounts and distributions of sedimentary components in the surface layer of Bikini lagoon.

In 1979 a portable winch powered by a gasoline engine was used to lower and raise a Shipek grab sampler. The winch contained 300 $\mathrm{m}$ of $0.5 \mathrm{~cm}$ diameter stainless steel hydrographic cable that passed through a metering sheave secured to the port-side davit of the Marshall Island research vessel, RV Liktanur. Sampling locations were preselected using a systematic sampling plan and treating the Atoll as a square grid to ensure all regions of the lagoon were sampled. Stations were separated approximately by 1.5 nautical miles. We deviated from this grid only when the overlying water depth at a station was too shallow for the research vessel or when the bottom material encountered was too difficult to sample. The crew of the vessel provided all fixes necessary for locating sampling positions. Upon reaching a designated site, the vessel stopped and the Shipek was lowered at a slow rate to the lagoon bottom. At some locations it was necessary to lower the Shipek repeaedly before an adequate sample was obtained. 


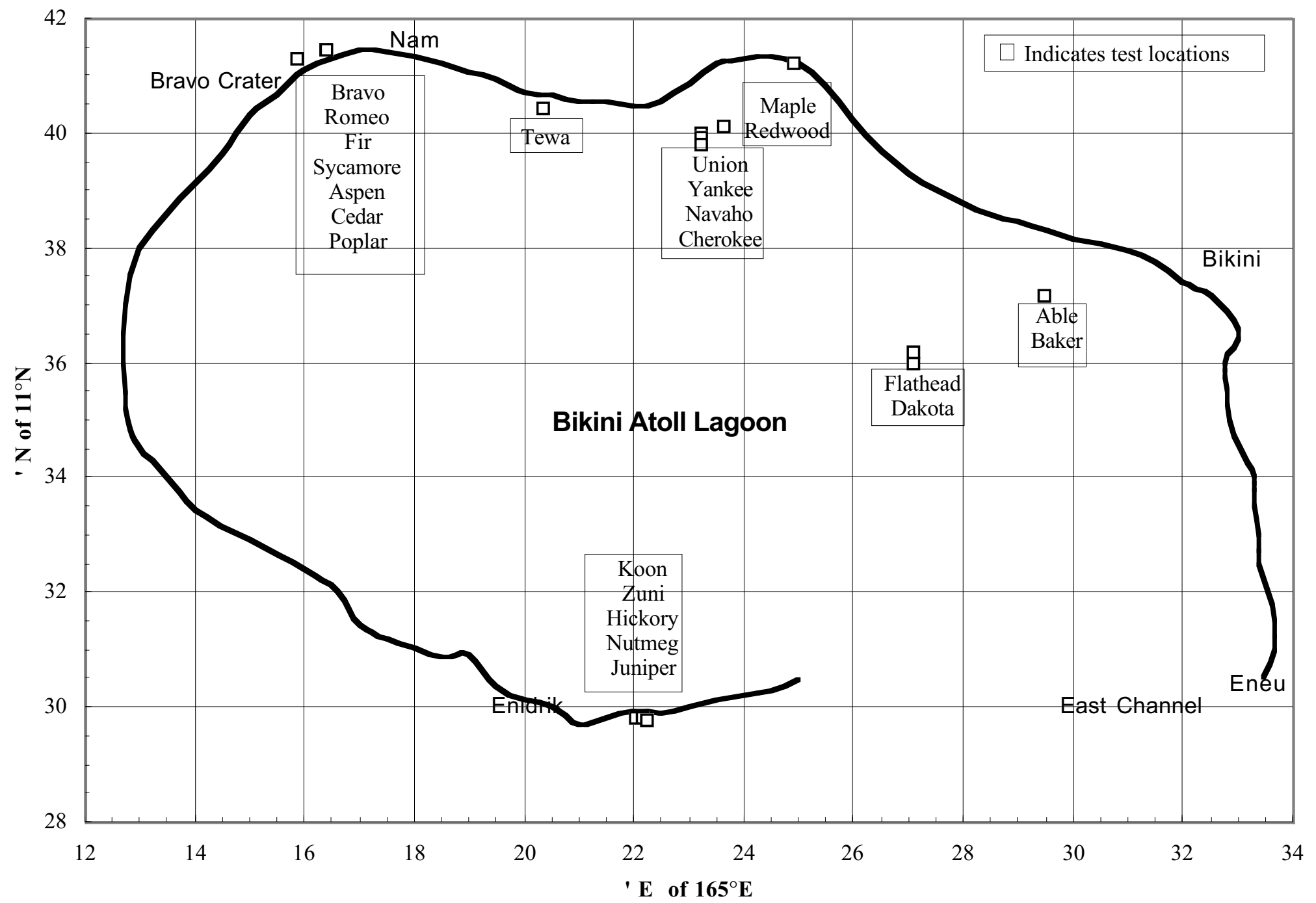

Figure 1. Names and Locations of Nuclear Tests at Bikini Atoll. 
Table 1. Test Site Data and Crater Dimensions.

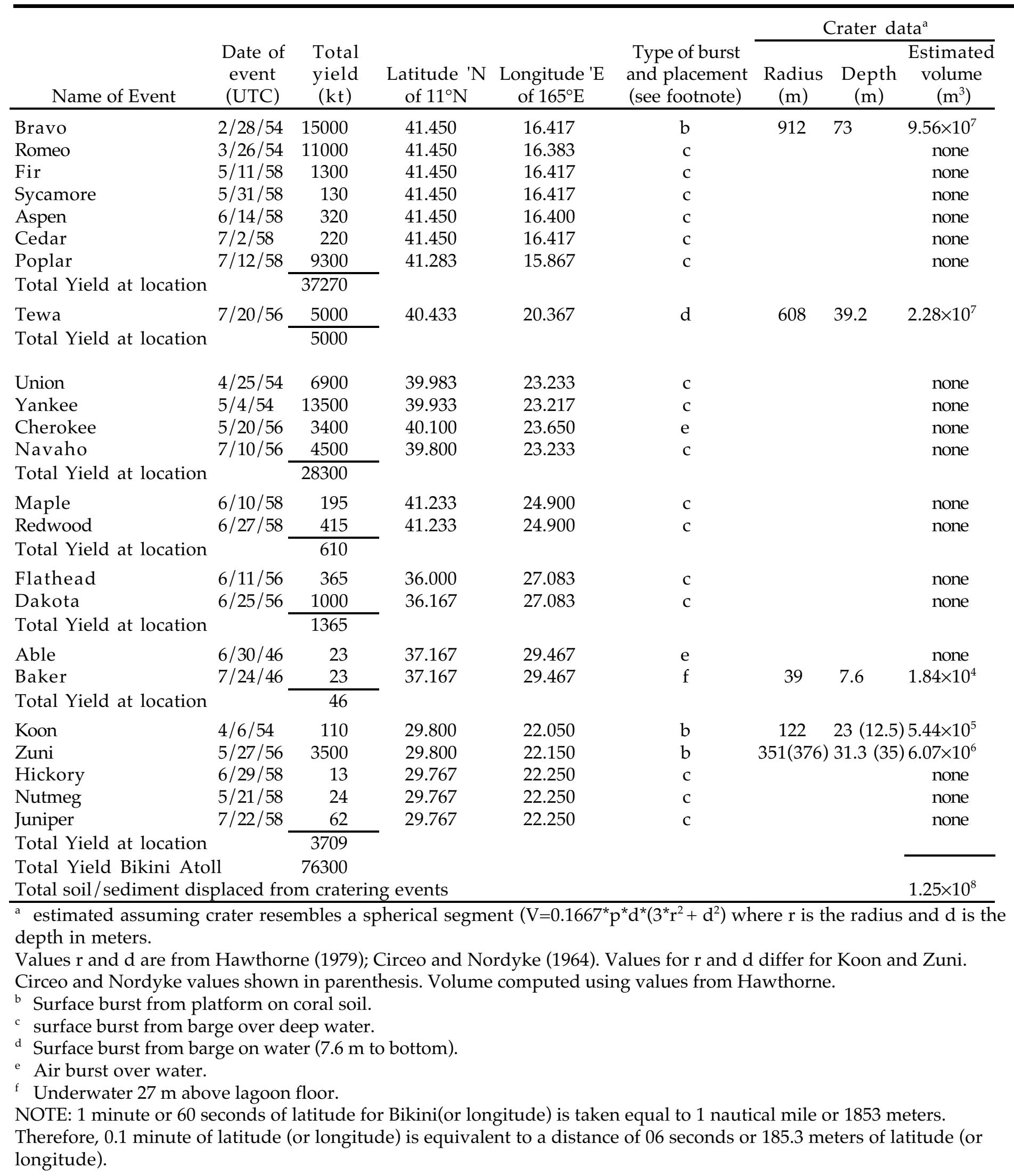


Penetration to depths in surface sediment was poor in areas containing high percentages of coarse sediments, shell fragments, and remains of species of Halimeda algae, and best in areas where the bottom sediment consisted of finegrained material. The contents of the grab were sub-sampled to depths of 2 and $4 \mathrm{~cm}$ with end caps and a short core. The volume of material sampled with one end cap to $2 \mathrm{~cm}$ was $39.3 \mathrm{~cm}^{3}$. Usually two to three surface subsamples were removed from each grab and combined as a sample for that station. The volume sampled to $4 \mathrm{~cm}$ with the short core was $102.1 \mathrm{~cm}^{3}$. The core was obtained after the 2 cmsubsamples were removed from the grab. This subsampling technique provided two series of dimensionally comparative surface sediment samples.
All samples were placed in plastic bags, frozen, and returned to the laboratories for processing and analysis. At LLNL the wet weight was determinedand then the samples were sieved through a $0.5 \mathrm{~mm}$ screen to separate the less than $0.5 \mathrm{~mm}$ fraction from the coarse components. Each fraction was dried and weighed and thefraction of fine material in the total dry sample was determined. The amount of Halimeda remains, shell fragments, and foraminifera in the coarse fraction was also estimated. Both the fine and coarse fractions were then ball milled and transferred to containers for analysis by gamma spectrometry using a series of calibrated $\mathrm{Ge}(\mathrm{Li})$ detection systems.

\section{Results}

The Appendix contains general information on the 0 to $2 \mathrm{~cm}$ sediment sections including sample ID, total sample volume, dry weight of fine and coarse sedimentary components, fine fraction in the total sample, location sampled, overlying water depths and some sampling notes. Table 2 contains measurements of the percentage of fine material; Foraminifera; Halimeda; and shell fragments in the 0 to $2 \mathrm{~cm}$ surface sediments samples collected in 1979. The last two columns contain the percentage of fine material in the 0 to $4 \mathrm{~cm}$ section of surface sediment and the ratio for the fraction of fine material in the 0 to $2 \mathrm{~cm}$ section relative to the fine material in the 0 to $4 \mathrm{~cm}$ section. Values for the quotient range from 0.2 to 1.8 and average 0.96 so that on the average, the same, or slightly smaller, fraction of fine material extends from the sediment surface to a depth of at least $4 \mathrm{~cm}$ in the sediment column.

\section{Discussion}

\section{Distributions}

Emery et al., (1954) plotted the percent abundance of the major sedimentary components. Lines of equal abundance were drawn through the 25, 50 and $75 \%$ abundance values. The weighted average composition showed Halimeda debris most abundant $(40 \%)$, followed by fine debris $(23 \%)$, coral $(20 \%)$, Foraminifera $(10 \%)$, mollusk shells $(6 \%)$ and miscellaneous material (1\%). Plots showing the lines of equal abundance in Bikini lagoon for fine material and Halimeda remains are enlarged from the original Emery et al., (1954) report and are shown in Figures 2 and 3. Emery et al. (1954) indicated that off the beaches fine debris was in appreciable quantities.
Wave action breaks the material near the beaches into fine debris that was carried up to 5 $\mathrm{km}$ into the lagoon. On the downwind side (western side) of the lagoon the area of most abundant fine debris was wide, irregular, and located further from shore than on the upwind side (eastern side). This pattern resulted from the greater wave action on the downwind side of the lagoon. The zone of fine debris appeared to be almost entirely absent along most of the upwind periphery from Aomoen island to Eneu island, except along Bikini island. Fine debris was less abundant near the middle of the lagoon, where it constitutes less than 10 percent of all components in each sample (stated by Emery et al., 1954, but not shown in Figure 2), because the depth was too great for 
Table 2. Description of Major Materials in Bikini Lagoon Surface Sediment Collected during April to June 1979.

\begin{tabular}{|c|c|c|c|c|c|c|c|c|}
\hline \multirow[b]{2}{*}{ Log ID } & \multirow{2}{*}{$\begin{array}{l}\text { Minutes } \\
\text { East of } \\
165^{\circ} \mathrm{E} \\
\mathrm{X} \text { coord } \\
\end{array}$} & \multirow{2}{*}{$\begin{array}{c}\text { Minutes } \\
\text { North of } 11^{\circ} \\
\mathrm{N} \\
\text { Y coord } \\
\end{array}$} & \multicolumn{4}{|c|}{ Components in $0-2 \mathrm{~cm}$ depth increments } & \multirow[b]{2}{*}{$\begin{array}{c}\text { Fines } \mathrm{s}^{\mathrm{a}} 0-4 \mathrm{~cm} \\
\text { fraction of } \\
\text { total } \mathrm{wt}\end{array}$} & \multirow[b]{2}{*}{$\begin{array}{l}\text { Ratio fines }{ }^{a} \\
0-2 \mathrm{~cm} / 0-4 \mathrm{~cm}\end{array}$} \\
\hline & & & $\begin{array}{c}\% \text { fines }^{\mathrm{a}} \\
\text { material } \\
\text { by wt }\end{array}$ & $\begin{array}{c}\% \text { shells- } \\
\text { coral } \\
\text { by wt } \\
\end{array}$ & $\begin{array}{c}\% \text { forams } \\
\text { by wt }\end{array}$ & $\begin{array}{c}\% \\
\text { Halimeda } \\
\text { by wt }\end{array}$ & & \\
\hline $4-22-79-1$ & 33.5 & 31 & 75 & 10 & 8 & 6 & & \\
\hline 2 & 32.5 & 30 & 18 & 73 & 3 & 7 & & \\
\hline 3 & 32.5 & 31.5 & 47 & 27 & 23 & 3 & 0.54 & 0.87 \\
\hline 4 & 32.5 & 33 & 42 & 35 & 6 & 16 & 0.42 & 1.00 \\
\hline 5 & 32.5 & 34.5 & 30 & 18 & 11 & 41 & 0.37 & 0.81 \\
\hline 6 & 32.5 & 36 & 89 & 4 & 4 & 3 & & \\
\hline 7 & 31 & 37.5 & 19 & 9 & 4 & 68 & & \\
\hline 9 & 28 & 37.5 & 34 & 14 & 10 & 42 & & \\
\hline 10 & 26.5 & 37.5 & 17 & 22 & 24 & 37 & 0.21 & 0.81 \\
\hline 11 & 26.5 & 36 & 6 & 7 & 15 & 72 & 0.06 & 1.08 \\
\hline 12 & 28 & 36 & 8 & 6 & 18 & 68 & 0.08 & 0.95 \\
\hline 13 & 29.5 & 36 & 10 & 10 & 32 & 48 & 0.06 & 1.69 \\
\hline 14 & 31 & 36 & 59 & 9 & 10 & 21 & & \\
\hline 4-23-79-1 & 29.5 & 34.5 & 38 & 11 & 23 & 28 & 0.39 & 0.98 \\
\hline 2 & 29.5 & 33 & 23 & 12 & 33 & 32 & 0.29 & 0.80 \\
\hline 3 & 29.5 & 31.5 & 41 & 31 & 10 & 18 & 0.48 & 0.85 \\
\hline $4-24-79-1$ & 26.5 & 31.5 & 42 & 33 & 10 & 16 & 0.51 & 0.82 \\
\hline $2 a$ & 26.5 & 33 & 13 & 11 & 24 & 52 & 0.17 & 0.74 \\
\hline $3 a$ & 26.5 & 34.5 & 6 & 4 & 18 & 72 & 0.1 & 0.62 \\
\hline 4 & 25 & 34.5 & 22 & 20 & 22 & 37 & 0.29 & 0.75 \\
\hline 5 & 23.5 & 34.5 & 3 & 6 & 7 & 84 & 0.05 & 0.60 \\
\hline 6 & 22 & 34.5 & 13 & 10 & 29 & 49 & 0.17 & 0.75 \\
\hline 7 & 20.5 & 34.5 & 11 & 14 & 5 & 70 & 0.08 & 1.35 \\
\hline 8 & 19 & 34.5 & 50 & 19 & 12 & 18 & 0.55 & 0.91 \\
\hline $9 a$ & 17.5 & 34.5 & 59 & 24 & 12 & 6 & & \\
\hline 10 & 16 & 34.5 & 77 & 11 & 10 & 3 & 0.76 & 1.01 \\
\hline 11 & 14.5 & 34.5 & 65 & 11 & 15 & 8 & 0.65 & 1.00 \\
\hline 12 & 14.5 & 36 & 74 & 6 & 6 & 13 & 0.76 & 0.98 \\
\hline 13 & 16 & 36 & 24 & 15 & 14 & 46 & 0.15 & 1.59 \\
\hline 14 & 16 & 37.5 & 44 & 36 & 8 & 12 & & \\
\hline 15 & 17.5 & 39 & 78 & 8 & 8 & 6 & 0.79 & 0.99 \\
\hline 17 & 20.5 & 39 & 100 & 0 & 0 & 0 & 1 & 1.00 \\
\hline $4-25-79-1$ & 19 & 40.5 & 52 & 7 & 3 & 38 & & \\
\hline 2 & 19 & 37.5 & 36 & 10 & 25 & 29 & 0.41 & 0.89 \\
\hline 3 & 19 & 36 & 13 & 42 & 26 & 19 & 0.14 & 0.89 \\
\hline 4 & 19 & 33 & 62 & 22 & 11 & 6 & 0.65 & 0.95 \\
\hline 5 & 19 & 31.5 & 63 & 18 & 13 & 5 & 0.6 & 1.05 \\
\hline 6 & 21.25 & 29.75 & 59 & 29 & 7 & 5 & 0.68 & 0.87 \\
\hline $6-15-79-1$ & 33.3 & 30.9 & 96 & 2 & 1 & 1 & 0.97 & 0.99 \\
\hline 2 & 31 & 31.5 & 65 & 18 & 11 & 6 & 0.66 & 0.99 \\
\hline 3 & 28 & 31.5 & 57 & 22 & 8 & 13 & 0.6 & 0.95 \\
\hline 4 & 25 & 31.5 & 42 & 30 & 9 & 19 & 0.28 & 1.50 \\
\hline 5 & 23.5 & 31.5 & 13 & 13 & 16 & 57 & 0.32 & 0.42 \\
\hline 6 & 22 & 31.5 & 48 & 26 & 10 & 16 & 0.65 & 0.74 \\
\hline 7 & 20.5 & 31.5 & 38 & 35 & 8 & 19 & 0.43 & 0.89 \\
\hline 8 & 17.5 & 31.5 & 67 & 19 & 9 & 5 & 0.62 & 1.08 \\
\hline
\end{tabular}


Table 2. Description of Major Materials in Bikini Lagoon Surface Sediment Collected April to June 1979 (continued).

\begin{tabular}{|c|c|c|c|c|c|c|c|c|}
\hline \multirow[b]{2}{*}{$\log$ ID } & \multirow[b]{2}{*}{$\begin{array}{l}\text { Minutes } \\
\text { East of } 165^{\circ} \mathrm{E} \\
\quad \mathrm{X} \text { coord }\end{array}$} & \multirow{2}{*}{$\begin{array}{l}\text { Minutes } \\
\text { North of } 11^{\circ} \\
\mathrm{N} \\
\text { Y coord }\end{array}$} & \multicolumn{4}{|c|}{ Components in $0-2 \mathrm{~cm}$ depth increments } & \multirow[b]{2}{*}{$\begin{array}{c}\text { Fines } 0-4 \mathrm{~cm} \\
\text { fraction of } \\
\text { total wt }\end{array}$} & \multirow[b]{2}{*}{$\begin{array}{l}\text { Ratio fines } \\
0-2 \mathrm{~cm} / 0-4 \mathrm{~cm}\end{array}$} \\
\hline & & & $\begin{array}{c}\% \text { fine } \\
\text { material } \\
\text { by wt }\end{array}$ & $\begin{array}{c}\% \text { shells- } \\
\text { coral } \\
\text { by wt }\end{array}$ & $\begin{array}{c}\% \text { forams } \\
\text { by wt }\end{array}$ & $\begin{array}{c}\% \\
\text { Halimeda } \\
\text { by wt }\end{array}$ & & \\
\hline $6-15-79-9$ & 16 & 32.8 & 33 & 43 & 12 & 12 & 0.33 & 1.00 \\
\hline 10 & 17.5 & 32.8 & 59 & 20 & 10 & 11 & 0.61 & 0.96 \\
\hline 11 & 20.5 & 32.8 & 64 & 11 & 8 & 17 & 0.64 & 1.00 \\
\hline 12 & 22 & 32.8 & 45 & 18 & 12 & 25 & 0.49 & 0.93 \\
\hline 13 & 23.5 & 32.8 & 66 & 26 & 5 & 3 & 0.78 & 0.84 \\
\hline 14 & 25 & 32.8 & 24 & 12 & 14 & 49 & 0.28 & 0.87 \\
\hline 15 & 28 & 32.8 & 56 & 12 & 13 & 19 & 0.48 & 1.16 \\
\hline 16 & 28 & 34.3 & 12 & 11 & 24 & 53 & 0.32 & 0.39 \\
\hline 17 & 31 & 32.8 & 8 & 5 & 22 & 65 & 0.07 & 1.17 \\
\hline 18 & 31 & 34.3 & 6 & 4 & 14 & 76 & 0.29 & 0.22 \\
\hline $6-16-79-1$ & 26.5 & 39 & 39 & 12 & 11 & 38 & & \\
\hline 2 & 25 & 39 & 90 & 4 & 2 & 4 & & \\
\hline 3 & 25 & 40.5 & 71 & 3 & 12 & 14 & & \\
\hline 4 & 23.5 & 40.5 & 50 & 7 & 14 & 28 & & \\
\hline 5 & 22 & 40.2 & 47 & 8 & 15 & 30 & & \\
\hline 6 & 20.5 & 40.2 & 86 & 2 & 2 & 10 & & \\
\hline 7 & 17.5 & 40.2 & 44 & 18 & 12 & 26 & 0.44 & 1.01 \\
\hline 8 & 16 & 40.2 & 100 & 0 & 0 & 0 & & \\
\hline 9 & 16 & 39 & 98 & 1 & 0 & 1 & 0.97 & 1.01 \\
\hline 10 & 14.5 & 39 & 95 & 1 & 3 & 2 & 0.96 & 0.98 \\
\hline 11 & 14.5 & 37.8 & 45 & 6 & 19 & 30 & 0.51 & 0.87 \\
\hline 12 & 17.5 & 37.7 & 22 & 12 & 26 & 40 & 0.3 & 0.74 \\
\hline 13 & 17.5 & 36 & 32 & 16 & 24 & 28 & 0.25 & 1.29 \\
\hline 14 & 20.5 & 36 & 8 & 4 & 19 & 69 & 0.29 & 0.27 \\
\hline 15 & 22 & 36 & 6 & 5 & 10 & 79 & 0.05 & 1.14 \\
\hline 16 & 23.5 & 36 & 8 & 6 & 37 & 49 & 0.13 & 0.63 \\
\hline 17 & 25 & 36 & 13 & 4 & 31 & 51 & 0.1 & 1.35 \\
\hline 18 & 25 & 37.7 & 10 & 10 & 25 & 55 & 0.06 & 1.60 \\
\hline 19 & 23.5 & 37.7 & 38 & 4 & 20 & 38 & 0.51 & 0.74 \\
\hline 20 & 22 & 37.7 & 9 & 4 & 20 & 67 & 0.11 & 0.80 \\
\hline 21 & 20.5 & 37.7 & 13 & 3 & 30 & 54 & 0.11 & 1.21 \\
\hline 22 & 22 & 39 & 48 & 11 & 8 & 32 & 0.6 & 0.80 \\
\hline 23 & 23.5 & 39 & 54 & 6 & 9 & 31 & 0.69 & 0.78 \\
\hline $6-17-79-1$ & 31 & 30.1 & 16 & 65 & 12 & 7 & & \\
\hline 2 & 29.5 & 30.1 & 31 & 51 & 9 & 9 & 0.42 & 0.75 \\
\hline 3 & 28 & 30.1 & 14 & 80 & 3 & 3 & 0.11 & 1.29 \\
\hline 4 & 26.6 & 30.3 & 19 & 68 & 7 & 7 & 0.26 & 0.72 \\
\hline 5 & 25.2 & 30.3 & 46 & 31 & 4 & 19 & 0.52 & 0.88 \\
\hline 6 & 23.5 & 30.5 & 76 & 8 & 6 & 11 & 0.71 & 1.06 \\
\hline 7 & 22 & 30.1 & 67 & 3 & 3 & 27 & 0.43 & 1.56 \\
\hline 8 & 20.5 & 30.4 & 65 & 18 & 9 & 9 & 0.36 & 1.79 \\
\hline
\end{tabular}

${ }^{a}$ fines $=$ fine materials 


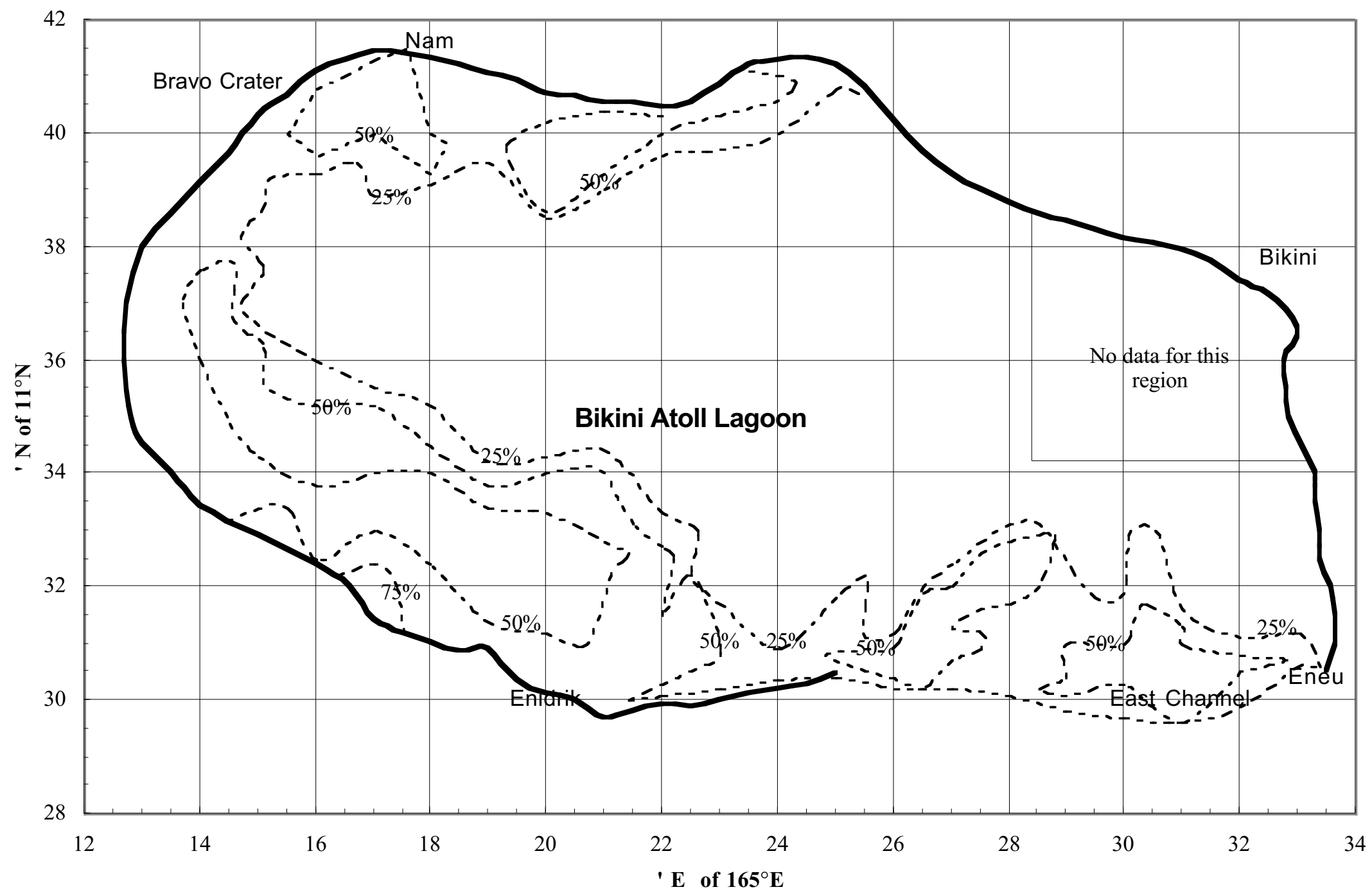

Figure 2. Distribution and percentage of abundance lines of fine material $(<0.5 \mathrm{~mm})$ in the surface of Bikini lagoon sediment sampled in 1946. 


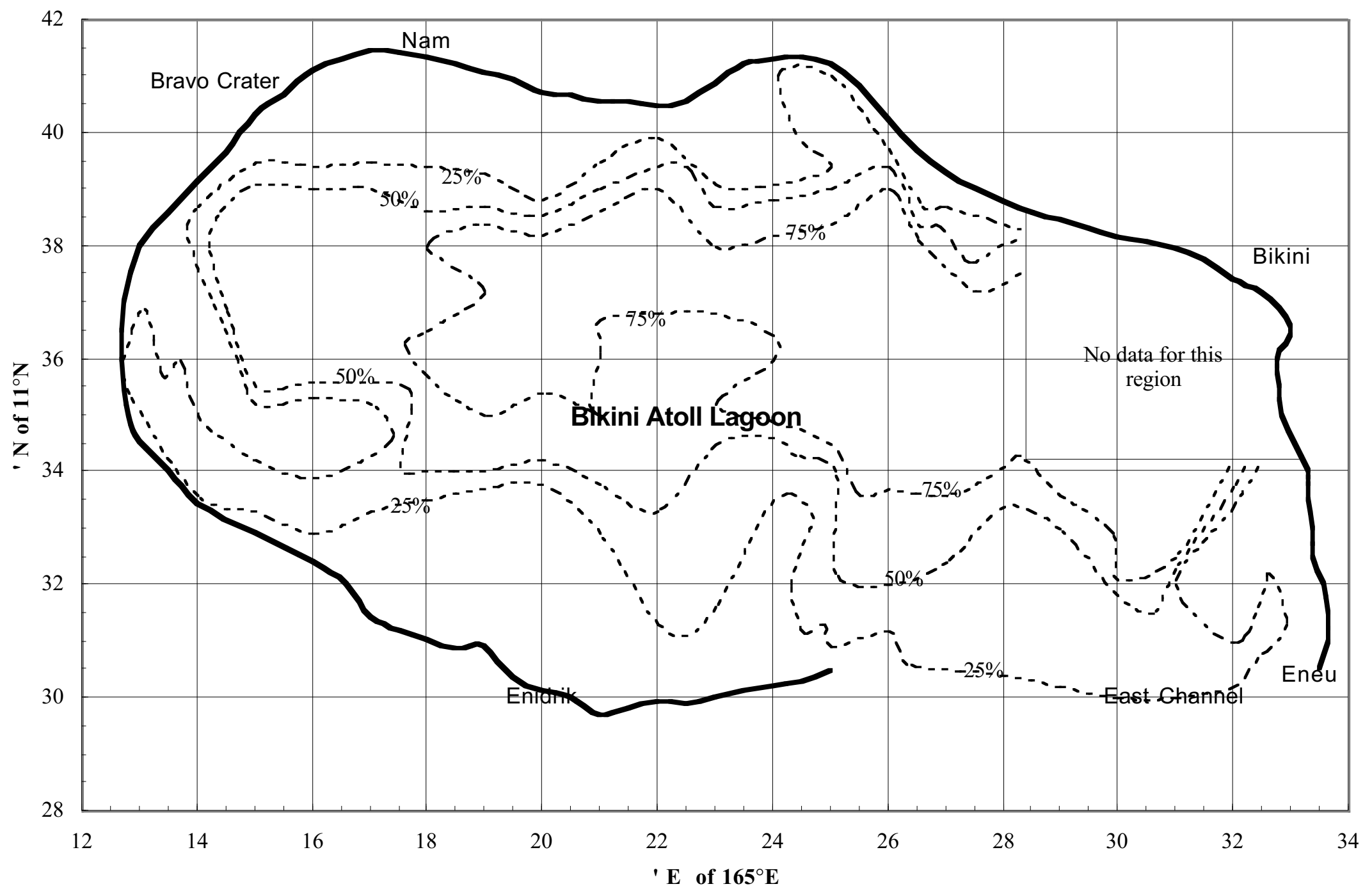

Figure 3. Distribution and percentage of abundance lines of the remains of Halimeda algae in the surface of Bikini lagoon sediment sampled in 1946. 
effective abrasion from waves and the distance from shore is too great for contributions from the beaches. The fine debris, therefore, had a ringlike distribution in the lagoon: open at the east end like a horseshoe.

There was an area of abundant Halimeda debris in middle and deeper part of the lagoon. Here the Halimeda segments made up at least $75 \%$ of each sample. The richest deposits were in the eastern half of the lagoon. Small regions of relatively low abundance of Halimeda generally coincided with the areas of abundant deeper-water Foraminifera. In water depths greater than about $55 \mathrm{~m}$, light was so reduced that live Halimeda plants do not flourish, or are absent. In these regions one found remains of pulverized algae that originated at, and was transported from, shallower depths.

\section{Distributions}

Figure 4 is developed from the results in Table 2 and shows the 25, 50 and 75\% abundance lines for fine debris in the 0 to $2 \mathrm{~cm}$ section of surface sediment. Figure 5 shows the lines for comparable abundance of Halimeda remains in the 1979 surface sediments. Many general features described by Emery et al. (1954) are also evident in the 1979 distributions. Highest amounts of fine debris are evident off the beaches and the most abundant deposits are on the upwind side of the lagoon. The smallest fractions are found in the middle of the lagoon but the area now defined by the $25 \%$ contour line is smaller than in 1946. There appears to be higher percentages of fine material at downwind and northern lagoon locations that are coincident with the major test locations shown in Figure 1. The mean percentage of fine material is listed in Table 3 and the regions bounded by lines of comparable abundance are shown in Figure 4. The area and fraction of the lagoon area of each section is also shown. From these values the mean percentage of fine material in the surface layer of the lagoon sediment is computed. It is estimated that the 1979 fine components now occupy $41 \pm 3 \%$ of the lagoon surface sediments compared to $23 \%$ estimated from the 1946 samples. The percentage of the lagoon floor occupied by coral-shell fragments, Foraminifera, and Halimeda decreased respectively to 17,13 , and $28 \%$ in 1979 . However the general features for
Halimeda debris abundance, shown in Figure 5, are somewhat similar to those described for the 1946 samples in Figure 3. Lowest amounts are around the inner perimeter of the lagoon with an abundance of 25 to $75 \%$ occupying the central section of the lagoon. The area defined by the 50 and $75 \%$ abundance lines for Halimeda are now substantially smaller than the area occupied in 1946 due to the higher percentage of fine material now found in the region. However the 1979 data no longer suggests any richer deposits in the eastern half of the lagoon as Emery et al. (1954) found in 1946.

Bikini lagoon has an area of $6.29 \times 10^{8} \mathrm{~m}^{2}$. The volume of sedimentary material to depths of 2 and $4 \mathrm{~cm}$ are $1.3 \times 10^{7}$ and $2.6 \times 10^{7} \mathrm{~m}^{3}$, respectively. In 1946, $23 \%$ of the surface sediment, or $2.9 \times 10^{6} \mathrm{~m}^{3}$ to $2 \mathrm{~cm}$ and $5.8 \times 10^{6} \mathrm{~m}^{3}$ to $4 \mathrm{~cm}$ depth, was fine debris.

In 1979 it is estimated that $41 \%$ of the material in the lagoon surface sediment is fine debris so that the volume of this material is $5.1 \times 10^{6} \mathrm{~m}^{3}$ to $2 \mathrm{~cm}$ depth and $10.3 \times 10^{6} \mathrm{~m}^{3}$ to 4 $\mathrm{cm}$ depth. There has been a net enrichment in fine debris of $2.2 \times 10^{6}$ and $4.5 \times 10^{6} \mathrm{~m}^{3}$ over the first 2 and $4 \mathrm{~cm}$ depth of the surface sediment layers.

From the dimensions of the five craters given by Hawthorne (1979), and shown in Table 1 , it is estimated that $1.25 \times 10^{8} \mathrm{~m}^{3}$ of soil and sediment were suspended during the cratering events. The amount of new fine in the lagoon to depths of 2 and $4 \mathrm{~cm}$, represents 1.8 and $3.6 \%$, respectively, of the volume of fine material generated during the cratering events. Therefore the five cratering events generated sufficient material to account for the inventory of new fine material found in the surface $4 \mathrm{~cm}$ of the lagoon floor. This assumes no contribution of fine material from any barge events which is a difficult scenario to imagine. Therefore the nuclear testing did increase (nearly doubled) the fraction of fine debris over the floor of the lagoon. This necessarily reduced the fractional contribution of the other major sedimentary components in surface layers from regions of the lagoon. Some amount of test-derived fine material must also be distributed to greater depths in the sediment column. However there is little data available tomake a reasonable estimate of the inventory of new material deeper than $4 \mathrm{~cm}$. 


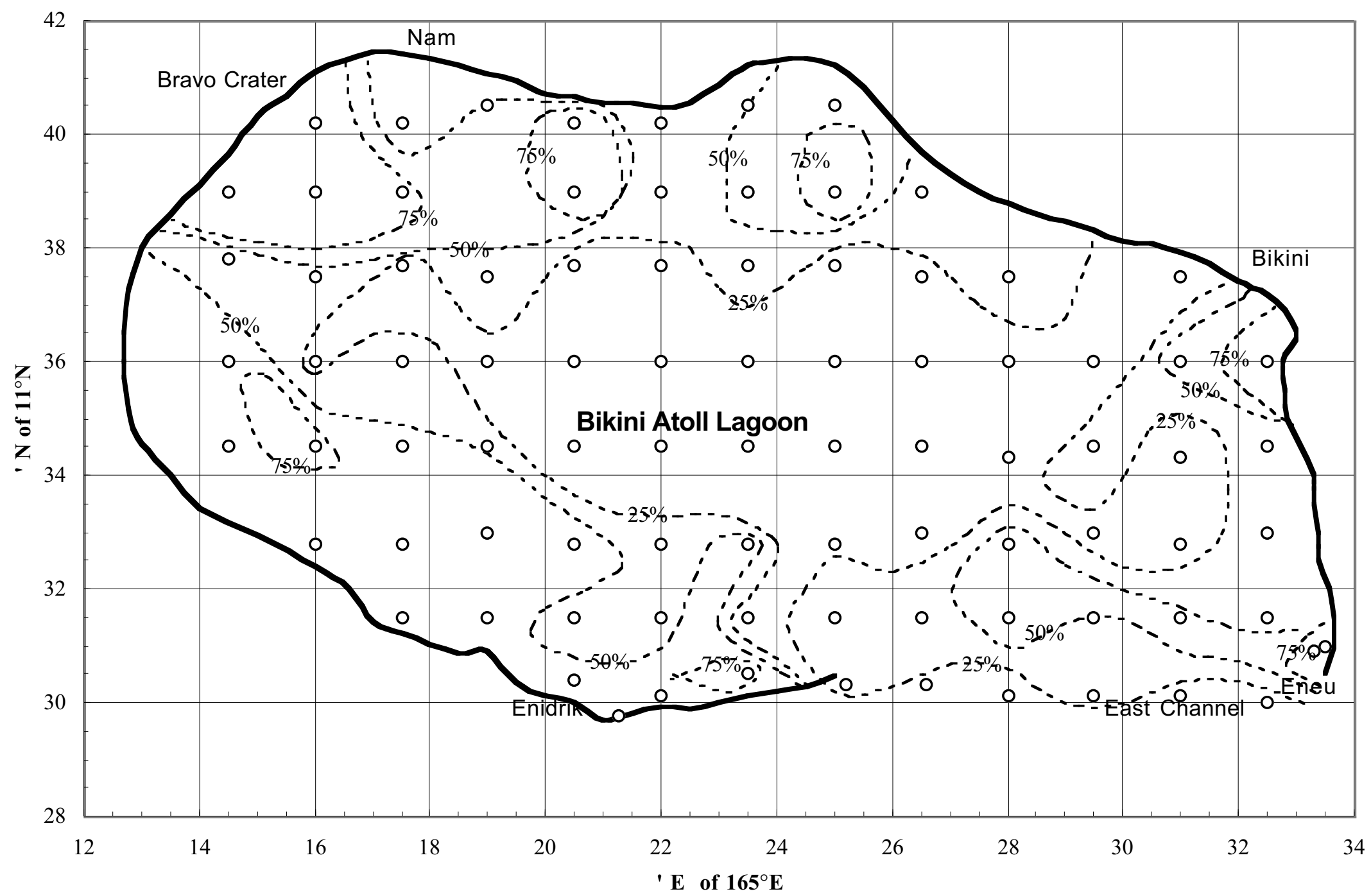

Figure 4. Station locations defined in Table 2 and percentage of abundance lines of fine material $(<0.5 \mathrm{~mm})$ inthe surface of Bikini lagoon sediment sampled in 1979. 


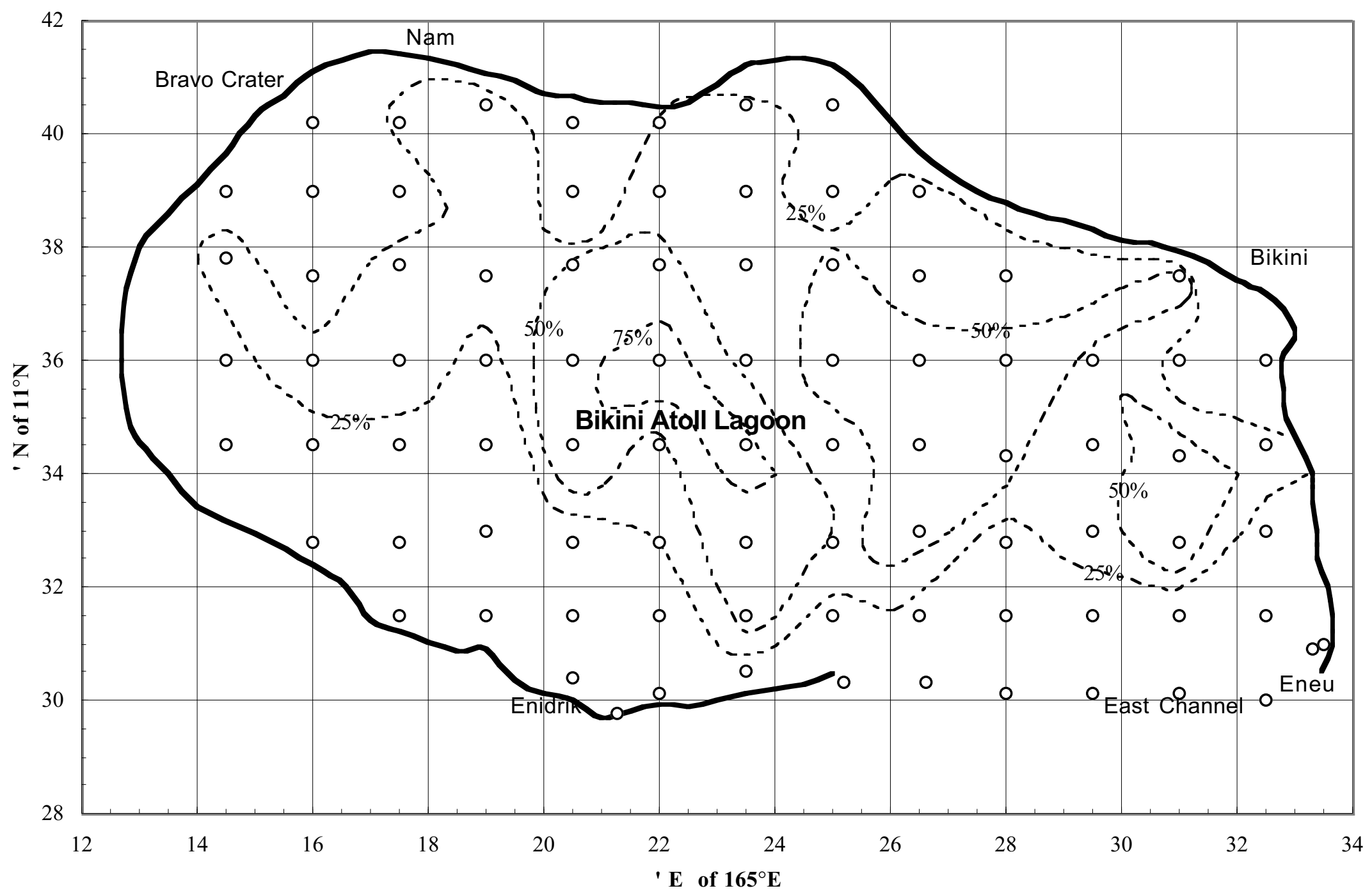

Figure 5. Station locations defined in Table 2 and percentage of abundance lines of the remains of Halimeda algae in the surface of Bikini lagoon sediment sampled in 1979. 
Table 3. Percentage of Fine Material in Surface $2 \mathrm{~cm}$ Layer of 1979 Bikini Lagoon Sediments

\begin{tabular}{lccr}
$\begin{array}{c}\text { Region described } \\
\text { by lines of equal } \\
\text { abundance }\end{array}$ & $\begin{array}{c}\text { Percentage of } \\
\text { of fines materials } \\
\text { in region }\end{array}$ & $\begin{array}{l}\text { Percent contribution } \\
\text { Lagoon area } \\
\text { covered with } \\
\text { fine material }\end{array}$ & $\begin{array}{c}\text { to amount } \\
\text { in entire } \\
\text { surface layer }\end{array}$ \\
\hline $\begin{array}{l}\text { sun }-25 \% \\
25 \%-50 \%\end{array}$ & $13.1 \pm 5.9$ & 32.4 & $4.2 \pm 1.9$ \\
$50 \%-75 \%$ & $40.5 \pm 5.6$ & 31.7 & $12.8 \pm 1.9$ \\
$75 \%-100 \%$ & $61.1 \pm 6.5$ & 27.1 & $16.6 \pm 1.9$ \\
Total \% fine materials in Surface Layer & $88.2 \pm 9.7$ & $8.8 \pm 0.6$ \\
\hline
\end{tabular}

In 1972, sediment and water samples were obtained from within Bravo Crater aboard the R.V. Palumbo from the Puerto Rico Nuclear Center (Noshkin et al., 1997b; Schell, et al., 1980). The maximum depth of overlying water in the center of the crater at this time was $47 \mathrm{~m}$. The original bottom depth of the crater was $73 \mathrm{~m}$. Subsequent events, coupled with redistribution processes and sedimentation, filled in the bottom $26 \mathrm{~m}$ of the crater since it was formed in late February 1954. This fill amounts to $1.21 \times 10^{7} \mathrm{~m}^{3}$ of fine sedimentary material and occupies approximately $13 \%$ of the original crater volume. Shell et al., (1980) found the ordering sequence of radionuclide concentrations in different sections of a $56 \mathrm{~cm}$ long core collected from the center of Bravo crater in 1972 differed greatly. They concluded that the radionuclides (and necessarily the sedimentary material) in the uppermost sections of sediment result from the post-Bravo tests conducted in the area. Thus, a mixture of sediments labeled with radionuclides from different tests have settled to partially fill the original crater. The volume of fill also represents a small fraction of the material generated in the cratering events alone.

\section{Conclusions}

Nuclear testing increased the fraction of finely divided material found in the surface sediment layer over large areas of the lagoon and especially in regions of the lagoon and reef adjacent to test sites. The increased fraction of fine material resulted from several processes including (1) direct fallout of material to the lagoon surface and subsequent deposition to the bottom sediments; (2) transport from reef flats initiated by internal waves generated during the explosions; and (3) resuspension of deposited ejecta from the nearby reefs or shallow regions and transport to other regions within the lagoon by natural processes. Although the fraction of fine material in the bottom sediments was altered by the nuclear events, the combined processes of formation, transport, and deposition were not sufficiently dynamic to alter the geographical features of the major sedimentary components such as fine debris and Halimeda remains over most of the lagoon floor.
It is assumed fine debris is more suitable than coarse debris for construction material. An abundance of fine material is (Circa, 1979) evident lagoonward of the eastern reef off Bikini and Eneu islands. The other reports in this series (Noshkin et al., 1997a; Noshkin et al., 1997b ) show that radionuclide levels in sedimentary material from this region of the lagoon is also low. This region might be suitable for dredging low activity fine material for construction of a causeway on the eastern reef especially if transport costs must also be considered and minimized. However reduced visibility caused by turbidity resulting from resuspension during dredging operations may cause problems both to the local marine ecosystem and recreational lagoon diving activities in the eastern section of the lagoon which formally began in 1996. Any impact from dredging operations must then also be considered before a marine sediment removal program is undertaken at the Atoll. 


\section{Acknowledgments}

The authors acknowledge the assistance of Mr. K. V. Marsh and Mr. J. Schweiger in collecting lagoon sediment samples. The work was performed under the auspices of the U. S. Department of Energy under contract number W-7405-Eng-48.

\section{References}

Circeo, L.J., Jr., and M.D. Nordyke (1964), Nuclear Cratering Experience at the Pacific Proving Grounds, USAEC Report, Lawrence Livermore Laboratory, Livermore, CA, UCRL-12172.

Emery, K.O., J.I. Tracy, and H.S. Ladd (1954), "Geology of Bikini and Nearby Atolls," Professional Paper 260-A, U.S. Geological Survey, U.S. Gov. Printing Office, Wash. D.C., pp 263.

Hawthorne, H.A. (1979), "Compilation of Local Fallout Data from Test Detonations 1945-1962," Extracted from DASA 1251, Vol. II-Oceanic U.S. Tests, Report DNA 1251-2-EX, Defense Nuclear Agency, Wash. D.C., pp 333.

Lawson J.E., Jr. (modified 5 Aug. 1996), Catalog of Known and Putative Nuclear Explosions from Unclassified Sources, http://www.pal.xgw.fi/hew/CATALOG, Oklahoma Geol. Survey Observatory, Leonard, OK.

Noshkin, V.E., R.J. Eagle, K.M. Wong, and W.L. Robison (1997a), Sediment Studies at Bikini Atoll. Part 2. Inventories of Transuranium Elements in Surface Sediments, Lawrence Livermore National Laboratory, Livermore, CA (In Preparation).

Noshkin, V.E., R.J. Eagle, J.L. Brunk, and W.L. Robison (1997b), Sediment Studies at Bikini Atoll. Part 3. Changes in Inventories of Long Lived Gamma Emitting Radionuclides in Suface Sediments, Lawrence Livermore National Laboratory, Livermore, CA (In Preparation).

Schell, W.R., F.G. Lowman, and R.P. Marshall (1980), Geochemistry of Transuranic Elements at Bikini Atoll. in Transuranic Elements in the Environment, W.C. Hansen, Ed., U.S. Dept. of Energy, Wash. D.C., Rept (DOE/TIC-22800). 
Appendix 
Appendix. Description of Bikini lagoon surface sediments $(0$ to $2 \mathrm{~cm}$ ) collected April to June 1979.

\begin{tabular}{|c|c|c|c|c|c|c|c|c|c|}
\hline $\log$ ID & MS\# & $\begin{array}{c}\text { Volume } \\
\text { sampled } \\
\mathrm{cm}^{3}\end{array}$ & $\begin{array}{l}\text { Dry wt } \\
\text { fine } \\
\text { and } \\
\text { coarse } \\
\text { fraction } \\
(\mathrm{g}) \\
\end{array}$ & $\begin{array}{c}\text { Total dry } \\
\text { sample } \\
\text { wt } \\
(\mathrm{g})\end{array}$ & $\begin{array}{l}\text { Fines; } \\
\text { fraction of } \\
\text { total wt }\end{array}$ & $\begin{array}{c}\text { Minutes } \\
\text { East of } \\
165^{\circ} \mathrm{E} \\
\text { X-coord } \\
\end{array}$ & $\begin{array}{c}\text { Minutes } \\
\text { North of } \\
11^{\circ} \mathrm{N} \\
\text { Y-coord } \\
\end{array}$ & $\begin{array}{c}\text { Water } \\
\text { Depth } \\
(\mathrm{m})\end{array}$ & Field Sampling Notes \\
\hline \multicolumn{10}{|c|}{ Note: $\mathrm{F}=$ fine; $\mathrm{C}=$ coarse fractions } \\
\hline $4-22-79-1 F$ & 7400 & 117.9 & 110.37 & & & 33.5 & 31 & 6 & 2; med. sand \\
\hline C & 7401 & 117.9 & 36.71 & 147.08 & 0.75 & & & & \\
\hline $2 \mathrm{~F}$ & 2 & 117.9 & 25.93 & & & 32.5 & 30 & 25 & 2; med. sand \\
\hline $\mathrm{C}$ & 3 & 117.9 & 121.3 & 147.23 & 0.18 & & & & \\
\hline $3 F$ & 4 & 117.9 & 63.21 & & & 32.5 & 31.5 & 49 & $1 ;$ med. sand \\
\hline $\mathrm{C}$ & 5 & 117.9 & 71.52 & 134.73 & 0.47 & & & & \\
\hline $4 \mathrm{~F}$ & 8 & 117.9 & 65.81 & & & 32.5 & 33 & 38 & 2; med. sand \\
\hline $\mathrm{C}$ & 9 & 117.9 & 90.14 & 155.95 & 0.42 & & & & \\
\hline $5 \mathrm{~F}$ & 12 & 117.9 & 33.47 & & & 32.5 & 34.5 & 31 & 2; Halimeda; med. sand \\
\hline $\mathrm{C}$ & 13 & 117.9 & 77.68 & 111.15 & 0.30 & & & & \\
\hline $6 \mathrm{~F}$ & 16 & 117.9 & 144.06 & & & 32.5 & 36 & 21 & 3; med. sand \\
\hline $\mathrm{C}$ & 17 & 117.9 & 17.28 & 161.34 & 0.89 & & & & \\
\hline $7 \mathrm{~F}$ & 18 & 117.9 & 14.02 & & & 31 & 37.5 & 25 & 7; Halimeda \\
\hline $\mathrm{C}$ & 19 & 117.9 & 58.84 & 72.86 & 0.19 & & & & \\
\hline $9 \mathrm{~F}$ & 22 & 78.6 & 33.37 & & & 28 & 37.5 & $29-39$ & 3; coral-Halimeda \\
\hline $\mathrm{C}$ & 23 & 78.6 & 63.59 & 96.96 & 0.34 & & & & \\
\hline $10 \mathrm{~F}$ & 24 & 117.9 & 20.27 & & & 26.5 & 37.5 & 49 & 1 ; coarse sand \\
\hline $\mathrm{C}$ & 25 & 117.9 & 98.87 & 119.14 & 0.17 & & & & \\
\hline $11 \mathrm{~F}$ & 28 & 117.9 & 3.77 & & & 26.5 & 36 & 49 & 1; coarse Halimeda \\
\hline $\mathrm{C}$ & 29 & 117.9 & 54.36 & 58.13 & 0.06 & & & & flakes \\
\hline $12 \mathrm{~F}$ & 32 & 117.9 & 4.58 & & & 28 & 36 & 51 & 1; coarse Halimeda \\
\hline $\mathrm{C}$ & 33 & 117.9 & 56 & 60.58 & 0.08 & & & & flakes \\
\hline $13 \mathrm{~F}$ & 36 & 117.9 & 7.94 & & & 29.5 & 36 & 45 & 1; Halimeda flakes \\
\hline $\mathrm{C}$ & 37 & 117.9 & 70.23 & 78.17 & 0.10 & & & & \& live plants \\
\hline $14 \mathrm{~F}$ & 40 & 117.9 & 93.35 & & & 31 & 36 & 48 & 1 ; fine sand \\
\hline $\mathrm{C}$ & 41 & 117.9 & 64.45 & 157.8 & 0.59 & & & & \\
\hline $4-23-79-1 F$ & 42 & 117.9 & 57.86 & & & 29.5 & 34.5 & 54 & 1 ; coarse-med. sand \\
\hline $\mathrm{C}$ & 43 & 117.9 & 94 & 151.86 & 0.38 & & & & \\
\hline $2 \mathrm{~F}$ & 46 & 117.9 & 23.17 & & & 29.5 & 33 & 56 & 1 ; coarse sand \\
\hline $\mathrm{C}$ & 47 & 117.9 & 77.03 & 100.2 & 0.23 & & & & \& Halimeda flakes \\
\hline $3 F$ & 50 & 117.9 & 70.72 & & & 29.5 & 31.5 & 44 & 4; med. sand \\
\hline $\mathrm{C}$ & 51 & 117.9 & 102.15 & 172.87 & 0.41 & & & & \\
\hline $4-24-79-1 F$ & 54 & 117.9 & 66.47 & & & 26.5 & 31.5 & 42 & 1 ; fine sand \\
\hline $\mathrm{C}$ & 55 & 117.9 & 92.22 & 158.69 & 0.42 & & & & \\
\hline $2 \mathrm{Fa}$ & 58 & 117.9 & 10.6 & & & 26.5 & 33 & $52-54$ & 3; dup. samples \\
\hline $\mathrm{C}$ & 59 & 117.9 & 73.9 & 84.5 & 0.13 & & & & 2A-Halimeda flakes \\
\hline $2 \mathrm{Fb}$ & 62 & 117.9 & 26.9 & & & & & & 2B-coarse sand \\
\hline $\mathrm{C}$ & 63 & 117.9 & 73.8 & 100.7 & 0.27 & & & & \& Halimeda flakes \\
\hline $3 \mathrm{Fa}$ & 66 & 117.9 & 3.7 & & & 26.5 & 34.5 & $52-53$ & 2; dup. samples \\
\hline $\mathrm{C}$ & 67 & 117.9 & 55.6 & 59.3 & 0.06 & & & & 3a-coarse Halimeda \\
\hline $3 \mathrm{Fb}$ & 70 & 117.9 & 2.1 & & & & & & 3b-coarse Halimeda \\
\hline $\mathrm{C}$ & 71 & 117.9 & 56 & 58.1 & 0.04 & & & & \\
\hline $4 \mathrm{~F}$ & 74 & 117.9 & 26.1 & & & 25 & 34.5 & 52 & 3; med. sand \& \\
\hline $\mathrm{C}$ & 75 & 117.9 & 94.7 & 120.8 & 0.22 & & & & few Halimeda flakes \\
\hline
\end{tabular}


Appendix. Description of Bikini lagoon surface sediments $(0$ to $2 \mathrm{~cm}$ ) collected April to June 1979.

Dry wt

fine

and Total dry Minutes Minutes

Volume coarse sample Fines; East of North of Water

sampled fraction wt fraction of $165^{\circ} \mathrm{E} \quad 11^{\circ} \mathrm{N}$ Depth

Log ID MS\# $\mathrm{cm}^{3} \quad(\mathrm{~g}) \quad(\mathrm{g})$ total $\mathrm{wt}$ X-coord Y-coord $(\mathrm{m})$ Field Sampling Notes

Note: $\mathrm{F}=$ fine; $\mathrm{C}=$ coarse fractions

\begin{tabular}{|c|c|c|c|c|c|c|c|c|c|}
\hline $5 \mathrm{~F}$ & 78 & 117.9 & 1.9 & & & 23.5 & 34.5 & 54 & 1; coarse Halimeda \\
\hline $\mathrm{C}$ & 79 & 117.9 & 61.1 & 63 & 0.03 & & & & \\
\hline $6 \mathrm{~F}$ & 82 & 117.9 & 8.2 & & & 22 & 34.5 & 54 & 1; coarse Halimeda \\
\hline $\mathrm{C}$ & 83 & 117.9 & 55.8 & 64 & 0.13 & & & & \\
\hline $7 \mathrm{~F}$ & 86 & 117.9 & 7.2 & & & 20.5 & 34.5 & 47 & 2; Halimeda flakes \\
\hline $\mathrm{C}$ & 87 & 117.9 & 59.6 & 66.8 & 0.11 & & & & \\
\hline $8 \mathrm{~F}$ & 90 & 117.9 & 82.2 & & & 19 & 34.5 & 49 & 1 ; medium sand \\
\hline $\mathrm{C}$ & 91 & 117.9 & 81.3 & 163.5 & 0.50 & & & & \\
\hline $9 \mathrm{Fa}$ & 92 & 117.9 & 66.7 & & & 17.5 & 34.5 & 54 & 2; dup samples \\
\hline $\mathrm{C}$ & 93 & 117.9 & 47.2 & 113.9 & 0.59 & & & & each $\mathrm{w}$ / fine sand \\
\hline $9 \mathrm{Fb}$ & 94 & 117.9 & 102.2 & & & & & & \\
\hline $\mathrm{C}$ & 95 & 117.9 & 57.9 & 160.1 & 0.64 & & & & \\
\hline $10 \mathrm{~F}$ & 96 & 117.9 & 145 & & & 16 & 34.5 & 48 & 1 ; fine sand \\
\hline $\mathrm{C}$ & 97 & 117.9 & 44.4 & 189.4 & 0.77 & & & & \\
\hline $11 \mathrm{~F}$ & 7500 & 117.9 & 113.3 & & & 14.5 & 34.5 & 44 & 2; fine sand \\
\hline $\mathrm{C}$ & 1 & 117.9 & 61.5 & 174.8 & 0.65 & & & & \\
\hline $12 \mathrm{~F}$ & 4 & 117.9 & 125.5 & & & 14.5 & 36 & 40 & 5; final-very fine mud \\
\hline $\mathrm{C}$ & 5 & 117.9 & 43 & 168.5 & 0.74 & & & & like crater material \\
\hline $13 \mathrm{~F}$ & 8 & 117.9 & 26.7 & & & 16 & 36 & 54 & 2; coarse \& med. sand \\
\hline $\mathrm{C}$ & 9 & 117.9 & 85.2 & 111.9 & 0.24 & & & & \\
\hline $14 \mathrm{~F}$ & 10 & 117.9 & 63.9 & & & 16 & 37.5 & 40 & 8;7 empty; final w/ fine \\
\hline $\mathrm{C}$ & 11 & 117.9 & 81.3 & 145.2 & 0.44 & & & & sand \\
\hline $15 \mathrm{~F}$ & 12 & 117.9 & 116.4 & & & 17.5 & 39 & 56 & 2; mud \\
\hline $\mathrm{C}$ & 13 & 117.9 & 32 & 148.4 & 0.78 & & & & \\
\hline $17 \mathrm{~F}$ & 20 & 117.9 & 145.2 & & & 20.5 & 39 & 59 & 1; fine mud \& sand \\
\hline $\mathrm{C}$ & 21 & 117.9 & 0.7 & 145.9 & 1.00 & & & & \\
\hline $4-25-79-1 F$ & 24 & 117.9 & 56.5 & & & 19 & 40.5 & $39-44$ & 4; coral \& fine sand \\
\hline $\mathrm{C}$ & 25 & 117.9 & 52.7 & 109.2 & 0.52 & & & & \\
\hline $2 \mathrm{~F}$ & 28 & 117.9 & 41.5 & & & 19 & 37.5 & 56 & 1; sand \& coarse \\
\hline $\mathrm{C}$ & 29 & 117.9 & 72.3 & 113.8 & 0.36 & & & & Halimeda flakes \\
\hline $3 F$ & 32 & 117.9 & 14.3 & & & 19 & 36 & $46-52$ & 5;5-coarse Halimeda \\
\hline $\mathrm{C}$ & 33 & 117.9 & 99.9 & 114.2 & 0.13 & & & & \& live plants \\
\hline $4 \mathrm{~F}$ & 36 & 117.9 & 106.7 & & & 19 & 33 & 51 & 2; med. sand \\
\hline $\mathrm{C}$ & 37 & 117.9 & 65.5 & 172.2 & 0.62 & & & & \\
\hline $5 \mathrm{~F}$ & 40 & 117.9 & 113.9 & & & 19 & 31.5 & 48 & $1 ;$ med. sand \\
\hline C & 41 & 117.9 & 66.2 & 180.1 & 0.63 & & & & \\
\hline $6 \mathrm{~F}$ & 44 & 117.9 & 102.3 & & & 21.25 & 29.75 & 31 & 1 ; med. sediment \\
\hline $\mathrm{C}$ & 45 & 117.9 & 70.6 & 172.9 & 0.59 & & & & \\
\hline $6-15-79-1 F$ & 48 & 78.6 & 102.5 & & & 33.3 & 30.9 & & $1 ;$ \\
\hline C & 49 & 78.6 & 4.5 & 107 & 0.96 & & & & \\
\hline $2 \mathrm{~F}$ & 52 & 78.6 & 66.9 & & & 31 & 31.5 & 48 & $1 ;$ \\
\hline C & 53 & 78.6 & 35.6 & 102.5 & 0.65 & & & & \\
\hline $3 F$ & 56 & 78.6 & 58.5 & & & 28 & 31.5 & 46 & $1 ;$ \\
\hline C & 57 & 78.6 & 44.4 & 102.9 & 0.57 & & & & \\
\hline
\end{tabular}


Appendix. Description of Bikini lagoon surface sediments $(0$ to $2 \mathrm{~cm}$ ) collected April to June 1979.

Dry wt

fine

and Total dry Minutes Minutes

Volume coarse sample Fines; East of North of Water

sampled fraction wt fraction of $165^{\circ} \mathrm{E} \quad 11^{\circ} \mathrm{N}$ Depth

Log ID MS\# $\mathrm{cm}^{3} \quad(\mathrm{~g}) \quad(\mathrm{g})$ total wt X-coord Y-coord $(\mathrm{m})$ Field Sampling Notes

Note: $\mathrm{F}=$ fine; $\mathrm{C}=$ coarse fractions

\begin{tabular}{|c|c|c|c|c|c|c|c|c|c|}
\hline $4 \mathrm{~F}$ & 60 & 78.6 & 44 & & & 25 & 31.5 & 44 & 1; Halimeda frag. \\
\hline $\mathrm{C}$ & 61 & 78.6 & 61 & 105 & 0.42 & & & & \\
\hline $5 \mathrm{~F}$ & 64 & 78.6 & 7.4 & & & 23.5 & 31.5 & 48 & 7; Halimeda debris \& \\
\hline $\mathrm{C}$ & 65 & 78.6 & 47.7 & 55.1 & 0.13 & & & & live plants; coral \\
\hline $6 \mathrm{~F}$ & 68 & 78.6 & 76.5 & & & 22 & 31.5 & 44 & 1 ; \\
\hline $\mathrm{C}$ & 69 & 78.6 & 82.5 & 159 & 0.48 & & & & \\
\hline $7 \mathrm{~F}$ & 72 & 78.6 & 41 & & & 20.5 & 31.5 & 42 & 1 ; \\
\hline $\mathrm{C}$ & 73 & 78.6 & 66.3 & 107.3 & 0.38 & & & & \\
\hline $8 \mathrm{~F}$ & 76 & 78.6 & 73.7 & & & 17.5 & 31.5 & 36 & 6 ; \\
\hline $\mathrm{C}$ & 77 & 78.6 & 36.7 & 110.4 & 0.67 & & & & \\
\hline $9 \mathrm{~F}$ & 80 & 78.6 & 34.1 & & & 16 & 32.8 & 32 & 1 ; coarse fragments \\
\hline $\mathrm{C}$ & 81 & 78.6 & 69.4 & 103.5 & 0.33 & & & & \\
\hline $10 \mathrm{~F}$ & 84 & 78.6 & 67.3 & & & 17.5 & 32.8 & 45 & 3 ; \\
\hline $\mathrm{C}$ & 85 & 78.6 & 47.5 & 114.8 & 0.59 & & & & \\
\hline $11 \mathrm{~F}$ & 88 & 78.6 & 63.8 & & & 20.5 & 32.8 & 54 & 1 ; \\
\hline $\mathrm{C}$ & 89 & 78.6 & 35.5 & 99.3 & 0.64 & & & & \\
\hline $12 \mathrm{~F}$ & 92 & 117.9 & 58.2 & & & 22 & 32.8 & 52 & $1 ;$ \\
\hline C & 93 & 117.9 & 70.1 & 128.3 & 0.45 & & & & \\
\hline $13 \mathrm{~F}$ & 96 & 78.6 & 70.2 & & & 23.5 & 32.8 & 57 & $1 ;$ \\
\hline C & 97 & 78.6 & 36.6 & 106.8 & 0.66 & & & & \\
\hline $14 \mathrm{~F}$ & 7600 & 78.6 & 17.2 & & & 25 & 32.8 & 54 & $1 ;+$ succulent algae \\
\hline $\mathrm{C}$ & 1 & 78.6 & 53.2 & 70.4 & 0.24 & & & & \\
\hline $15 \mathrm{~F}$ & 4 & 78.6 & 55.7 & & & 28 & 32.8 & 56 & 1; some live Halimeda \\
\hline $\mathrm{C}$ & 5 & 78.6 & 44.3 & 100 & 0.56 & & & & \\
\hline $16 \mathrm{~F}$ & 8 & 78.6 & 7.5 & & & 28 & 34.3 & 59 & 1; live Halimeda; \\
\hline $\mathrm{C}$ & 9 & 78.6 & 52.9 & 60.4 & 0.12 & & & & coral frags.; shrimp \\
\hline $17 \mathrm{~F}$ & 12 & 78.6 & 3.4 & & & 31 & 32.8 & 53 & 3; live Halimeda; \\
\hline C & 13 & 78.6 & 38.2 & 41.6 & 0.08 & & & & dead urchin \\
\hline $18 \mathrm{~F}$ & 16 & 78.6 & 2.9 & & & 31 & 34.3 & 47 & 3; Halimeda frag. \\
\hline C & 17 & 78.6 & 41.8 & 44.7 & 0.06 & & & & few live plants \\
\hline $6-16-79-1 F$ & 20 & 78.6 & 26.5 & & & 26.5 & 39 & 38 & 3 ; lots of coral \\
\hline $\mathrm{C}$ & 21 & 78.6 & 41.9 & 68.4 & 0.39 & & & & \\
\hline $2 \mathrm{~F}$ & 22 & 78.6 & 89.7 & & & 25 & 39 & 54 & 12; small sed. \\
\hline $\mathrm{C}$ & 23 & 78.6 & 9.5 & 99.2 & 0.90 & & & & for 2 end caps only \\
\hline $3 F$ & 24 & 78.6 & 57.3 & & & 25 & 40.5 & 20 & 1 \\
\hline $\mathrm{C}$ & 25 & 78.6 & 23.5 & 80.8 & 0.71 & & & & \\
\hline $4 \mathrm{~F}$ & 26 & 78.6 & 45 & & & 23.5 & 40.5 & 25 & 2; Halimeda frag. \\
\hline $\mathrm{C}$ & 27 & 78.6 & 44.6 & 89.6 & 0.50 & & & & \& live plants \\
\hline $5 \mathrm{~F}$ & 28 & 78.6 & 29.8 & & & 22 & 40.2 & 20 & 1 ; lots of infauna \\
\hline $\mathrm{C}$ & 29 & 78.6 & 33.8 & 63.6 & 0.47 & & & & and Halimeda \\
\hline $6 \mathrm{~F}$ & 30 & 78.6 & 83.8 & & & 20.5 & 40.2 & 35 & 2 \\
\hline $\mathrm{C}$ & 31 & 78.6 & 14.2 & 98 & 0.86 & & & & \\
\hline $7 F$ & 32 & 78.6 & 37.5 & & & 17.5 & 40.2 & 45 & 2; Halimeda frag. \\
\hline $\mathrm{C}$ & 33 & 78.6 & 47.3 & 84.8 & 0.44 & & & & \\
\hline
\end{tabular}


Appendix. Description of Bikini lagoon surface sediments $(0$ to $2 \mathrm{~cm}$ ) collected April to June 1979.

Dry wt

fine

and Total dry Minutes Minutes

Volume coarse sample Fines; East of North of Water

sampled fraction wt fraction of $165^{\circ} \mathrm{E} \quad 11^{\circ} \mathrm{N}$ Depth

$\log$ ID $\quad$ MS\# $\mathrm{cm}^{3}$ (g)

(g) total wt X-coord Y-coord

(m) Field Sampling Notes

Note: $\mathrm{F}=$ fine; $\mathrm{C}=$ coarse fractions

\begin{tabular}{|c|c|c|c|c|c|c|c|c|c|}
\hline $8 \mathrm{~F}$ & 36 & 78.6 & 96.7 & & & 16 & 40.2 & 44 & 1 ; fine material \\
\hline $\mathrm{C}$ & 37 & 78.6 & 0.3 & 97 & 1.00 & & & & \\
\hline $9 \mathrm{~F}$ & 38 & 78.6 & 91.9 & & & 16 & 39 & 59 & 1 ; very fine crater \\
\hline $\mathrm{C}$ & 39 & 78.6 & 1.7 & 93.6 & 0.98 & & & & ejecta \\
\hline $10 \mathrm{~F}$ & 42 & 78.6 & 88.5 & & & 14.5 & 39 & 43 & 2; fines $\mathrm{w} /$ shell frag. \\
\hline $\mathrm{C}$ & 43 & 78.6 & 5.1 & 93.6 & 0.95 & & & & worm tubes \\
\hline $11 \mathrm{~F}$ & 46 & 78.6 & 41 & & & 14.5 & 37.8 & 48 & 1; fines \& shell frag. \\
\hline $\mathrm{C}$ & 47 & 78.6 & 51 & 92 & 0.45 & & & & live algae unknown \\
\hline $12 \mathrm{~F}$ & 50 & 78.6 & 15.1 & & & 17.5 & 37.7 & 57 & 2; fines; shell frag. \\
\hline $\mathrm{C}$ & 51 & 78.6 & 53.2 & 68.3 & 0.22 & & & & halim. frag. \\
\hline $13 \mathrm{~F}$ & 54 & 117.9 & 32.4 & & & 17.5 & 36 & 56 & 2; fines; shell frag. \\
\hline $\mathrm{C}$ & 55 & 117.9 & 67.9 & 100.3 & 0.32 & & & & halim. frag. \\
\hline $14 \mathrm{~F}$ & 58 & 117.9 & 5.7 & & & 20.5 & 36 & 55 & 2; halim. frag. \\
\hline $\mathrm{C}$ & 59 & 117.9 & 68.1 & 73.8 & 0.08 & & & & \\
\hline $15 \mathrm{~F}$ & 62 & 117.9 & 3.1 & & & 22 & 36 & 55 & 1; halim. frag. \& live \\
\hline $\mathrm{C}$ & 63 & 117.9 & 51.1 & 54.2 & 0.06 & & & & \\
\hline $16 \mathrm{~F}$ & 66 & 117.9 & 5.5 & & & 23.5 & 36 & 58 & 2; Halimeda frag. \\
\hline $\mathrm{C}$ & 67 & 117.9 & 61.6 & 67.1 & 0.08 & & & & no live plants \\
\hline $17 \mathrm{~F}$ & 70 & 117.9 & 9.2 & & & 25 & 36 & 59 & 1; halim. frag. \& \\
\hline $\mathrm{C}$ & 71 & 117.9 & 59 & 68.2 & 0.13 & & & & live plants \\
\hline $18 \mathrm{~F}$ & 74 & 117.9 & 5.4 & & & 25 & 37.7 & 57 & 6; Halimeda frag. \\
\hline $\mathrm{C}$ & 75 & 117.9 & 51 & 56.4 & 0.10 & & & & \\
\hline $19 \mathrm{~F}$ & 78 & 117.9 & 35 & & & 23.5 & 37.7 & 49 & 1; halimed. frag. \\
\hline $\mathrm{C}$ & 79 & 117.9 & 57.8 & 92.8 & 0.38 & & & & \& live plants \\
\hline $20 \mathrm{~F}$ & 82 & 117.9 & 5.4 & & & 22 & 37.7 & 57 & 7; halim. frag \& live \\
\hline $\mathrm{C}$ & 83 & 117.9 & 56 & 61.4 & 0.09 & & & & shell frag. \\
\hline $21 \mathrm{~F}$ & 86 & 117.9 & 11 & & & 20.5 & 37.7 & 58 & 2; halim. frags. \\
\hline $\mathrm{C}$ & 87 & 117.9 & 71.6 & 82.6 & 0.13 & & & & \\
\hline $22 \mathrm{~F}$ & 90 & 117.9 & 60.5 & & & 22 & 39 & 48 & 1; halim. frag. coral \\
\hline $\mathrm{C}$ & 91 & 117.9 & 65.1 & 125.6 & 0.48 & & & & lace coral \\
\hline $23 \mathrm{~F}$ & 94 & 117.9 & 86.6 & & & 23.5 & 39 & 50 & 1 ; fine \& coarse sand \\
\hline $\mathrm{C}$ & 95 & 117.9 & 74.4 & 161 & 0.54 & & & & \\
\hline $6-17-79-1 F$ & 98 & 117.9 & 25.4 & & & 31 & 30.1 & 22 & $1 ;$ coarse sand \\
\hline $\mathrm{C}$ & 99 & 117.9 & 132.3 & 157.7 & 0.16 & & & & \\
\hline $2 \mathrm{~F}$ & 7700 & 117.9 & 53.8 & & & 29.5 & 30.1 & 29 & 2; fine-coarse sand \\
\hline $\mathrm{C}$ & 1 & 117.9 & 117.6 & 171.4 & 0.31 & & & & \\
\hline $3 F$ & 4 & 117.9 & 24.3 & & & 28 & 30.1 & 13 & 1 ; fine-coarse sand \\
\hline $\mathrm{C}$ & 5 & 117.9 & 146.5 & 170.8 & 0.14 & & & & \\
\hline $4 \mathrm{~F}$ & 8 & 117.9 & 29.7 & & & 26.6 & 30.3 & 19 & 4; fine-coarse sand \\
\hline $\mathrm{C}$ & 9 & 117.9 & 129.2 & 158.9 & 0.19 & & & & filamentous algae \\
\hline $5 \mathrm{~F}$ & 12 & 117.9 & 76.8 & & & 25.2 & 30.3 & 36 & 1 ; fines \& algae frag. \\
\hline $\mathrm{C}$ & 13 & 117.9 & 90.5 & 167.3 & 0.46 & & & & \\
\hline $6 \mathrm{~F}$ & 16 & 117.9 & 128.2 & & & 23.5 & 30.5 & 31 & 1 ; fine sediment ; \\
\hline $\mathrm{C}$ & 17 & 117.9 & 41.4 & 169.6 & 0.76 & & & & shell frags. \\
\hline
\end{tabular}


Appendix. Description of Bikini lagoon surface sediments (0 to $2 \mathrm{~cm}$ ) collected April to June 1979.

Dry wt

fine

and Total dry Minutes Minutes

Volume coarse sample Fines; East of North of Water

sampled fraction wt fraction of $165^{\circ} \mathrm{E} \quad 11^{\circ} \mathrm{N}$ Depth

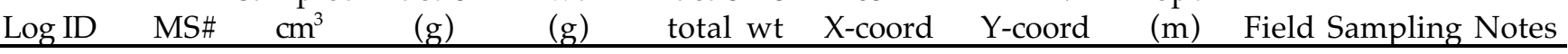

Note: $\mathrm{F}=$ fine; $\mathrm{C}=$ coarse fractions

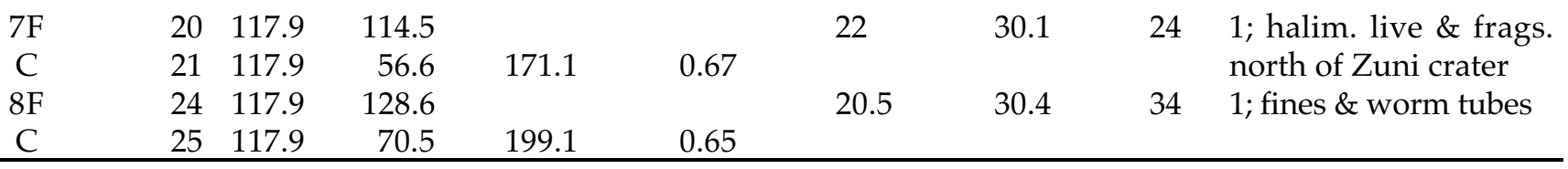

First number in notes indicates number of Shipek grab samplers attempted to obtain an adaquate sample.

Station locations provided by X \& Y coordinates.

$\mathrm{a}$ and $\mathrm{b}$ samples are replicates $0-2 \mathrm{~cm}$ surface sections at station from different Shipek grab samples. 


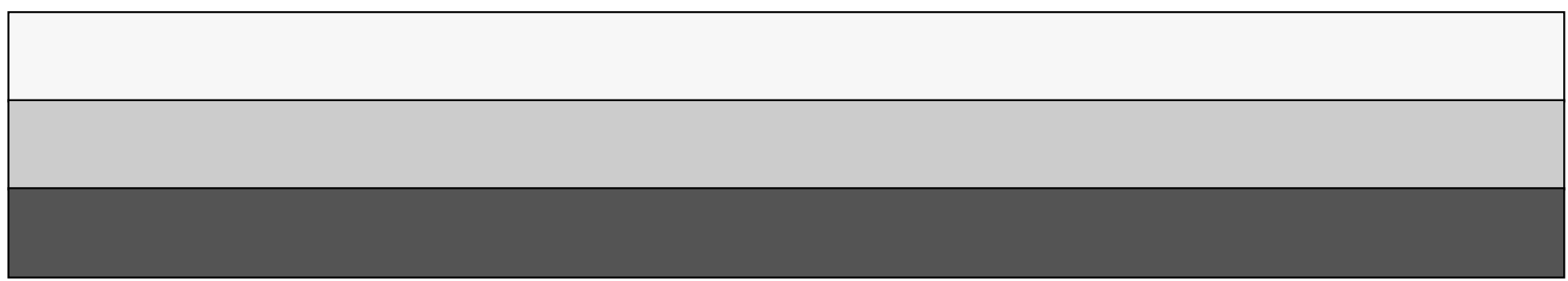

